\title{
Effect of organic fertilizers on physical attribute and organoleptic properties of Lettuce varieties
}

Nadia Sajjad ${ }^{1 *}$, Fazal Muhammad Bangulzai ${ }^{2}$, Najma Yousaf Zahid ${ }^{1}$, Najeebullah Khan ${ }^{1}$, Muhammad Ashraf ${ }^{2}$, Rehmat Ali Baloch ${ }^{2}$, Abdul Gaffar $^{2}$, Muhammad Ilyas ${ }^{2}$ and Dad Muhammad Baloch ${ }^{2}$

1. PMAS Arid Agriculture University Rawalpindi-Pakistan

2. Agriculture Research Institute (A.R.I) Sariab Quetta, Balochistan-Pakistan

*Corresponding author's email: fazalbangulzai786@gmail.com

Citation

Nadia Sajjad, Fazal Muhammad Bangulzai, Najma Yousaf Zahid, Najeebullah Khan, Muhammad Ashraf, Rehmat Ali Baloch, Abdul Gaffar, Muhammad Ilyas and Dad Muhammad Baloch. Effect of organic fertilizers on physical attribute and organoleptic properties of Lettuce varieties. Pure and Applied Biology. Vol. 9, Issue 2, pp1637-1645. http://dx.doi.org/10.19045/bspab.2020.90172

\begin{tabular}{llll}
\hline \hline Received: 00/12/2019 & Revised: 00/02/2020 & Accepted: 00/03/2020 & Online First: 24/03/2020 \\
\hline \hline
\end{tabular}

\section{Abstract}

The research trail was conducted in the field of Horticulture PMAS Arid Agriculture University Rawalpindi during2015-16 using 3 replicated RCBD. Two varities of Lettuce grand rapid and icebergwere tested. Physical Attribute data i.e. Number of leaves, Plant height, Total leaf Area per Plant, Fresh plant Weight, Leaf dry weight and organoleptic properties were observed. The average number of leaves mean between the two varieties was observed to be highly significant. Ice-berg lettuce produced maximum number of leaves with average mean 8.98. Grand rapid lettuce produced highest leaf length with average mean $14.82 \mathrm{~cm}$ compared with ice-berg lettuce which produced leaf length with average mean $12.34 \mathrm{~cm}$. In case of ice-berg lettuce, maximum area was depicted in plants grown in $\mathrm{T}_{1}$ that was $93.07 \mathrm{~cm}^{2}$. Ice-berg lettuce produced heavier leaf with $501.3 \mathrm{~g}$ compared with grand rapid lettuce $(308.6 \mathrm{~g})$. Leaf dry weight of ice-berg lettuce $(16.4 \mathrm{~g})$ showed significant difference with grand rapid lettuce with $9.8 \mathrm{~g}$. In grand rapid lettuce highest dry matter is recorded in $\mathrm{T}_{1}$ with dry weight of $14 \mathrm{~g}$. The highest significant values for aroma were 4.5 and 3.5, found in lettuce grown in $\mathrm{T}_{1}$ and $\mathrm{T}_{2}$, respectively. But least values were 2.6 and 2.1 in $\mathrm{T} 2$ (V2) and T3 (V1) respectively .All the physical attributes were highly significant among treatments and varities. From this study it was observed that hybrid varity ice-berg is better than grand rapid morphologically. Where as in treatments, T1 (chicken manure) was good with regards to physical attribute.

Keywords: Growth; Physical attribute; Lettuce; Organic Fertilizers; Organoleptic Properties; Varieties

\section{Introduction}

Lettuce, scientifically known as Lactuca sativa $\mathrm{L}$. is generally found in mixture of sandwiches and salad as well as a vital component in nutrition and diet of west countries. Lettuces were fresh vegetables consumed in the United States the 2nd largest at 28.0 pounds/capita in 2008 , after 36.7 
pounds of potatoes[1].Lettuce belongs to the family of Asteraceae, the tribe of more than 100 species Lactuca Cichorieae, only three that are (Lactucavirosa L., Lactucaserriola L., and Lactucasaligna L.) can pass to the crossbar spleen by traditional breeding methods and thus represent the most essential breeding group. They are all diploids with $2 n=$ fertilize $2 \mathrm{x}=18$ chromosomes [2]. There are five most important types of lettuce plant which are romaine lettuce, crisphead lettuce also known as iceberg, butterhead lettuce, stem lettuce and leaf lettuce in which Stem lettuce is largely shaped and produced in people republic of China. In the year of 2010, up to $58 \%$ of the production was generated in the United States was head type lettuce, up to $29 \%$ was romaine lettuce and $13 \%$ was leaf types [3].

The most common lettuce which is mostly consumed especially in fast foods and restaurants are Iceberg [4]. This most popular vegetables in salads are utilized in escalating amounts because of its perception as being "healthier" foods [5]. The vigorous properties are recognized due to huge delivery of antioxidant mainly polyphenols, fiber contents as well as vitamin C [6]. Polyphenols (anthocyanins and flavonols) was described of having greater antioxidant action than vitamins $\mathrm{C}$ and $\mathrm{E}$ [7].

The organic production of vegetables using dung and manure are also gaining energy in the area [8]. The substrates comprise organic materials, such as wood chips, barks, coconut fibers, dehydrated moss and peat [9]. Soil and peat moss when mixed, it boosts water retention capability and works as a buffer caused by fertilizer application. Chicken manure is an excellent fertilizer used because it has high content of nutrient, especially for Potassium, Nitrogen and Phosphorus. Manures decompose in the soil and discharge nutrients for yield to uptake. The availability of chicken manure also reduces the costs of fertilizers in the production of vegetables. Chicken manure is basically the organic waste from poultry[10]. Manure are generally referred to the waste materials of cattle's and chicken also known as organic material and other massive, natural substances that are mixed with soil in order to enhance and improve the productivity and health of crops [11].

Positive amounts of numerous central components are present in lettuce, such as antioxidants, Phenol, calcium, iron, vitamins $A$ and $C$ etc. In local medication, seeds of lettuce are utilized in crush form for the curing of asthma, pertussis, rhinitis and cough and its extract is engaged as a sedative as well as for the cure of insomnia. Moreover, the Seeds oil extract have painkiller outcome after applying externally on the head [12].

\section{Materials and methods}

The research trial was carried out in the field area of Horticulture Department Pir Mehr Ali Shah-University of Arid Agriculture Rawalpindi in the year 2015-2016. Healthy and disease free seeds of two varities of lettuce grand rapid and ice-berg (local and hybrid) were taken and sown in pots contains soil, silt, and farm yard manure in the ratio of 1:1:1inmonth of October 2015 as shown in (Table 1). Soil was thoroughly prepared by adding well rotten farm yardmanure one month before bed preparation. Land was prepared by ploughing the field twice followed by planking and seedlings were transplanted. After 40 days, healthy seedling were transplanted on well prepared raised beds according to recommended spacing for both hybrid and local lettuce, P-P distance was $15-20 \mathrm{~cm}$ and B-B distance was $50 \mathrm{~cm}$, All treatments were replicated three times with following treatments.

\section{Physical attribute}

Morphological data were taken in the University research field. The data from both varieties (hybrid and local). 
Table 1. List of four organic fertilizers with specific concentration and ratios

\begin{tabular}{|c|c|c|c|}
\hline Treatments & Code & Concentrations & Ratio \\
\hline $\mathrm{T}_{0}$ & Control & Soil & \\
\hline $\mathrm{T}_{1}$ & Chicken manure + compost & $5 \mathrm{~kg} / \mathrm{bed}$ & $1: 1$ \\
\hline $\mathrm{T}_{2}$ & Compost + peat moss & $5 \mathrm{~kg} / \mathrm{bed}$ & $1: 1$ \\
\hline $\mathrm{T}_{3}$ & Peat moss + chicken manure + compost & $5 \mathrm{~kg} / \mathrm{bed}$ & $1: 1: 1$ \\
\hline
\end{tabular}

The data on following traits was recorded at pre and post-harvest

\section{Number of leaves}

Number of outer and inner leaves per randomly selected lettuces plants from both varieties (hybrid and local) was taken at harvesting stage with three replications.

\section{Total leaf area per plant $\left(\mathrm{cm}^{2}\right)$}

The measurement of leaf area of both varities was taken from randomly selected plants of both local and hybrid lettuce at harvesting and then calculated to get maximum width and length. For the accurate measurement plastic scale was used[13]formula was used to get the total leaf area per plant using.

Leaf area $=$ maximum width $\mathrm{x}$ maximum length x 0.74

After performing calculation the average leaf area was taken.

\section{Fresh plant weight (gm)}

Fresh plant weight from all the treatments at the time of harvest was taken in grams and compared with controlled. Electronic weighing balance was used for measuring weight in order to ensure the correct measurement.

\section{Leaf Dry weight(gm)}

Dry matter contents of the powdered leaf samples from both varities of lettuce (hybrid and local) were determined by oven drying at $105^{\circ} \mathrm{C}$ until a constant weight was obtained [14].

\section{Organoleptic properties}

Quality parameters including flavours, taste and quality was found out by organized team of individuals. The panel decide taste, crispness and flavor according to their taste preferences to check Phenolic level.

\section{Statistical analysis}

The study was conducted with a completely randomized design (RCBD) with four treatments, two varieties and three replicates in the field and the Complete Randomized Design (CRD) was followed in the laboratory of Horticulture Department Pir Mehr Ali Shah-University of Arid Agriculture Rawalpindi. The data will be subjected to Analysis of Variance (ANOVA)and least significant difference (LSD) test was used to compare differences between treatments at 5 $\%$ level of significance.

\section{Results and discussion}

In the present study two varieties of Lettuce, grand rapid and ice-berg (local and hybrid) were grown in four different treatments of organic fertilizers. The data concerning various growth and production parameters of lettuce influenced by different growth substrates was collected and statistically analyzed which are discussed as following,

\section{Physical attribute analysis}

Number of leaves

The average number of leaves mean between the two varieties was observed to be highly significant. Apparently, ice-berg lettuce produced maximum number of leaves with average mean 8.98 leaves per plant compared with grand rapid lettuce which produced maximum number of leaves with average mean 6 leaves per plant as shown in (Table $2 \&$ Fig. 1) respectively. This could be attributed to differences in the varietal characteristic of the two lettuce verities.

It was observed that the lettuce varieties grown in $T_{1}$ treatment (Chicken manure + compost) exhibited the highest value with 8.46 leaves per plant. Those grown in $\mathrm{T}_{2}$ treatment (Compost + peat moss) followed with average mean of 7.45 leaves per plant. It was succeeded by $\mathrm{T}_{3}$ treatment (Peat moss+ 
chicken+ compost) with average mean of 7.25 leaves per plant and the lowest value was found to be those grown in $\mathrm{T}_{0}$ treatment (Control) with average mean of 6.8 leaves per plant. Maximum number of leaves were shown by $\mathrm{V}_{2}$ variety (ice-berg lettuce) (10.33) grown in $T_{1}$ treatment (Chicken manure + compost). This means that treatment with different organic fertilizers highly affected the yield of lettuce.

The current research result are also in accordance with work of Masarirambi et al. [15], who conducted an experiment to assess the effects of organic fertilizers on yield and quality of lettuce grown in river sand. With different organic fertilizers i.e. (a) bounce back compost, (b) cattle manure and (c) chicken manure. Lettuce plants fertilized with chicken manure had relatively higher average number of leaves per plant as compared to other organic fertilizers. The need and consumption of chicken manure has surpasses the use of other animal manure, because of its high content of potassium, phosphorus and nitrogen chicken manure is preferred amongst other animal wastes due to its high concentration of macro nutrients [16]. In addition, application of chicken manure to soil enhances concentration of water soluble salts in soil. significant increases of $\mathrm{N}(50 \%)$ and $\mathrm{P}(80 \%)$ were observed following addition of chicken manure [17].

Table 2. Number of leaves in lettuce varieties grown with different manure treatments

\begin{tabular}{|c|c|c|c|}
\hline Treatments & grand rapid & ice-berg & Mean \\
\hline Control & $5.3 \mathrm{ab}$ & $8.3 \mathrm{a}$ & $\mathbf{6 . 8 a}$ \\
\hline Chicken manure + compost & $6.6 \mathrm{a}$ & $10.33 \mathrm{~b}$ & $\mathbf{8 . 4 6 a}$ \\
\hline Compost + peat moss & $5.6 \mathrm{ab}$ & $9.3 \mathrm{a}$ & $\mathbf{7 . 4 5 a}$ \\
\hline Peat moss+ chicken manure + compost & $6.5 \mathrm{a}$ & $8 \mathrm{a}$ & $\mathbf{7 . 2 5 a}$ \\
\hline Mean & $\mathbf{6 a}$ & $\mathbf{8 . 9 8}$ & \\
\hline
\end{tabular}

Means in the same column or row followed by a common letter (s) are not significantly different at 5\% level by LSD

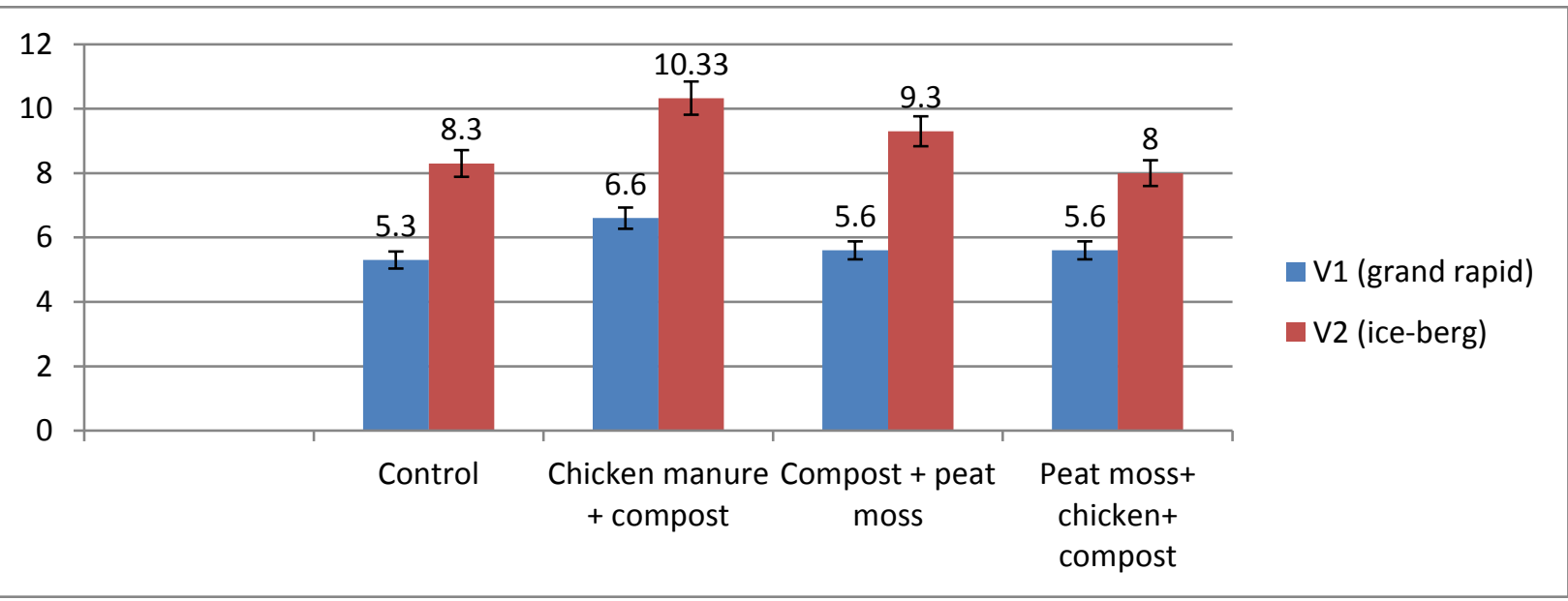

Figure 1. Increase in number of leaves per plant for grand rapid and ice-berg lettuces with four different manure treatment

\section{Total leaf area per plant $\left(\mathrm{cm}^{2}\right)$}

Results were significant for leaf area at the time of lettuce harvest. In case of ice-berg lettuce, maximum area was shown in plants grown in $\mathrm{T}_{1}$ treatment (Chicken manure + compost) that was $93.07 \mathrm{~cm}^{2}$ followed by $\mathrm{T}_{3}$ treatment (Peat moss+ chicken+ compost) and $\mathrm{T}_{0}$ treatment (Control) which was 66.85 
and $66.00 \mathrm{~cm}^{2}$ respectively and were not greatly different from each other. However least leaf area was recorded in plants grown in $\mathrm{T}_{2}$ treatment (Compost + peat moss) that was $61.08 \mathrm{~cm}^{2}$. In grand rapid lettuce, it was observed that plants grown in $T_{1}$ treatment (Chicken manure + compost) had higher leaf area $\left(73.13 \mathrm{~cm}^{2}\right)$ followed by $\mathrm{T}_{2}$ treatment (Compost + peat moss) with leaf area 59.24 $\mathrm{cm}^{2}$ that is not greatly different from $\mathrm{T}_{3}$ treatment (Peat moss+ chicken+ compost) means and the least being expressed against $\mathrm{T}_{0}$ treatment (Control) $\left(39.89 \mathrm{~cm}^{2}\right)$ as shown in (Table 3\&Fig. 2) respectively.

The present findings are also similar with the results of the earlier researchers as documented that indicated significant $(\mathrm{P}<0.05)$ differences in leaf area index $(\mathrm{LAI})$ amongst treatments. The lettuce fertilized with chicken manure eventually exhibited relatively higher LAI, followed by lettuce grown using cattle manure.

It was found by Dayananda and Whundeniya[18] that long root length is responsible for higher leaf area because longer roots absorb more nutrients from the soil that will result in larger area. Chicken manure + compost in combination with other media e.g. peat, gives good results because of good aeration and absorption of nutrients from media mixtures give higher yields as compared to other media combinations. Chicken manure is preferred amongst other animal wastes due to its high concentration of macro nutrients [16]. In addition, application of chicken manure to soil enhances concentration of water soluble salts in soil.

Table 3. Leaf area $\left(\mathrm{cm}^{2}\right)$ in lettuce varieties grown with different manure treatments

\begin{tabular}{|c|c|c|c|}
\hline Treatments & grand rapid & ice-berg & Mean \\
\hline Control & $39.89 \mathrm{ab}$ & $\mathbf{6 6 . 0 0 b}$ & $\mathbf{5 2 . 9 4 b}$ \\
\hline Chicken manure + compost & $73.13 \mathrm{a}$ & $93.07 \mathrm{a}$ & $\mathbf{8 3 . 1 0 a}$ \\
\hline Compost + peat moss & $59.24 \mathrm{~b}$ & $61.08 \mathrm{~b}$ & $\mathbf{6 0 . 1 6 b}$ \\
\hline Peat moss + chicken manure + compost & $45.97 \mathrm{ab}$ & $66.85 \mathrm{~b}$ & $\mathbf{5 6 . 4 1 b}$ \\
\hline Mean & $\mathbf{7 1 . 7 5 a}$ & $\mathbf{6 3 . 1 5 b}$ & \\
\hline
\end{tabular}

Means in the same column or row followed by a common letter (s) are not significantly different at 5\% level by LSD

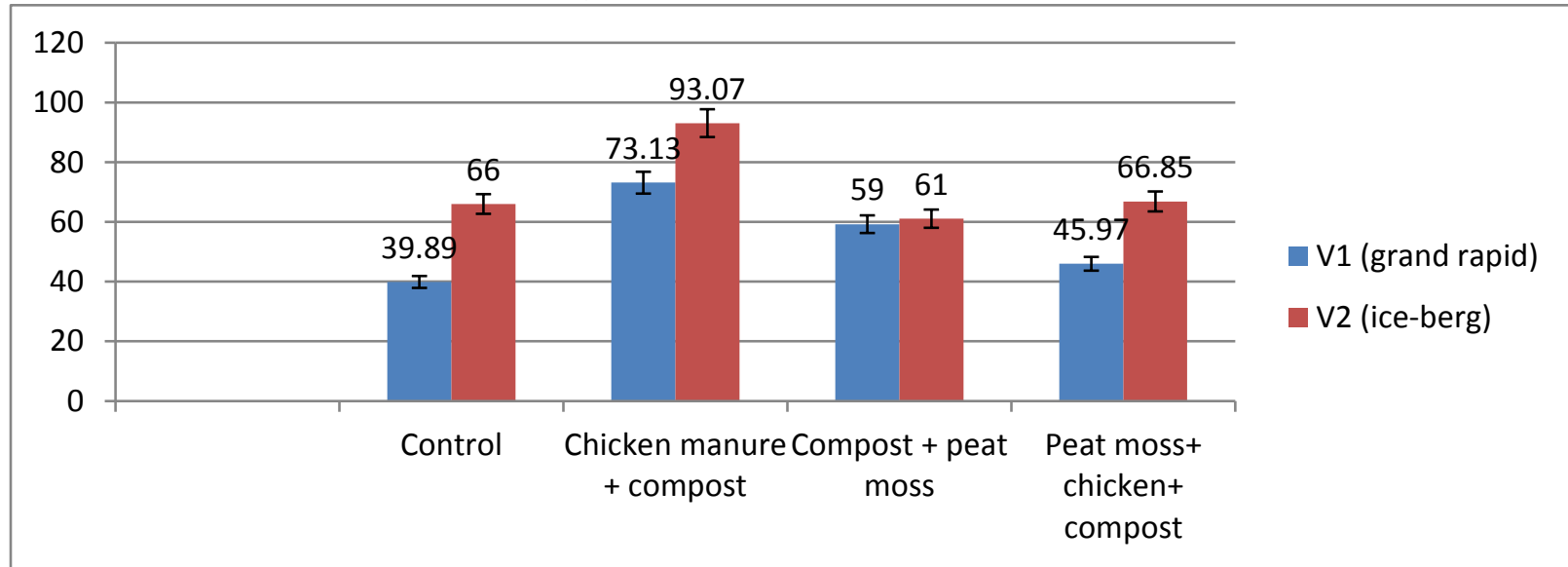

Figure 2. Comparison between mean values of Leaf Area of two Lettuce Varieties grand rapid and ice-berg using four different manure treatments

Fresh plant weight (gm)

Results for fresh plant weight after harvesting have been presented in (Table 4) which represents the mean values for all the treatments applied to both varieties of lettuce i.e. grand rapid and ice-berg. The average leaf 
fresh weight between the two varieties was observed to be highly significant. Apparently, ice-berg lettuce produced heavier leaf with $501.3 \mathrm{~g}$ compared with grand rapid lettuce (308.6g). This could be attributed to differences in the varietal characteristic of the two lettuce varieties.

Results revealed significance differences for the fresh plant weight in all the treatments. In grand rapid best plant weight was observed in the plants grown under $\mathrm{T}_{1}$ treatment (Chicken manure + compost) (308.6 g) followed by $\mathrm{T}_{2}$ (Compost + peat moss) $(233.6 \mathrm{~g})$. And the least weight was observed in the plants grown in $T_{3}$ (Peat moss + chicken+ compost) $(79.33$ g). For ice-berg maximum head mass was observed in $\mathrm{T}_{1}$ treatment (Chicken manure + compost) (501.3 g). Least mass was recorded in the plants grown under $\mathrm{T}_{3}$ (Peat moss + chicken + compost) (136.3 g).

The variation among mean values of other treatments is his significantly different from highest and lowest values. The current research also supports the report of Masarirambi et al. [15]. According to study fresh weight was higher in those plants which were grown in the organic fertilizers as compared to other inorganic fertilizers. In an experiment performed by Dayananda and Whundeniya[18], Chicken manure was designated as the best media for fresh and dry plant weight. Chicken manure not only provides high nutrient contents $(\mathrm{N}, \mathrm{P}$, and $\mathrm{K})$ in comparison with chemical fertilizer, but also adds organic matters to the soil to improve soil structure, aeration, soil moisture-holding capacity, and water infiltration. Manure applied to field plots also risked the subsurface water and groundwater quality if handled improperly. A comparison between plant weights for both varieties has been presented in (Fig. 3).

Table 4. Plant fresh weight in lettuce varieties grown with different manure treatments

\begin{tabular}{|c|c|c|c|}
\hline Treatments & grand rapid & ice-berg & Mean \\
\hline Control & $128.6 \mathrm{c}$ & $\mathbf{2 3 0 b}$ & $\mathbf{1 7 9 . 3 c}$ \\
\hline Chicken manure + compost & $308.6 \mathrm{a}$ & $501.3 \mathrm{a}$ & $\mathbf{4 0 5 a}$ \\
\hline Compost + peat moss & $233.6 \mathrm{~b}$ & $337.6 \mathrm{a}$ & $\mathbf{2 8 5 . 6 b}$ \\
\hline Peat moss+ chicken manure + compost & $79.33 \mathrm{bc}$ & $136.3 \mathrm{c}$ & $\mathbf{1 0 7 . 8 c}$ \\
\hline Mean & $\mathbf{1 8 7 . 5 b}$ & $\mathbf{3 0 1 . 3 b}$ & \\
\hline
\end{tabular}

Means in the same column or row followed by a common letter (s) are not significantly different at 5\% level by LSD

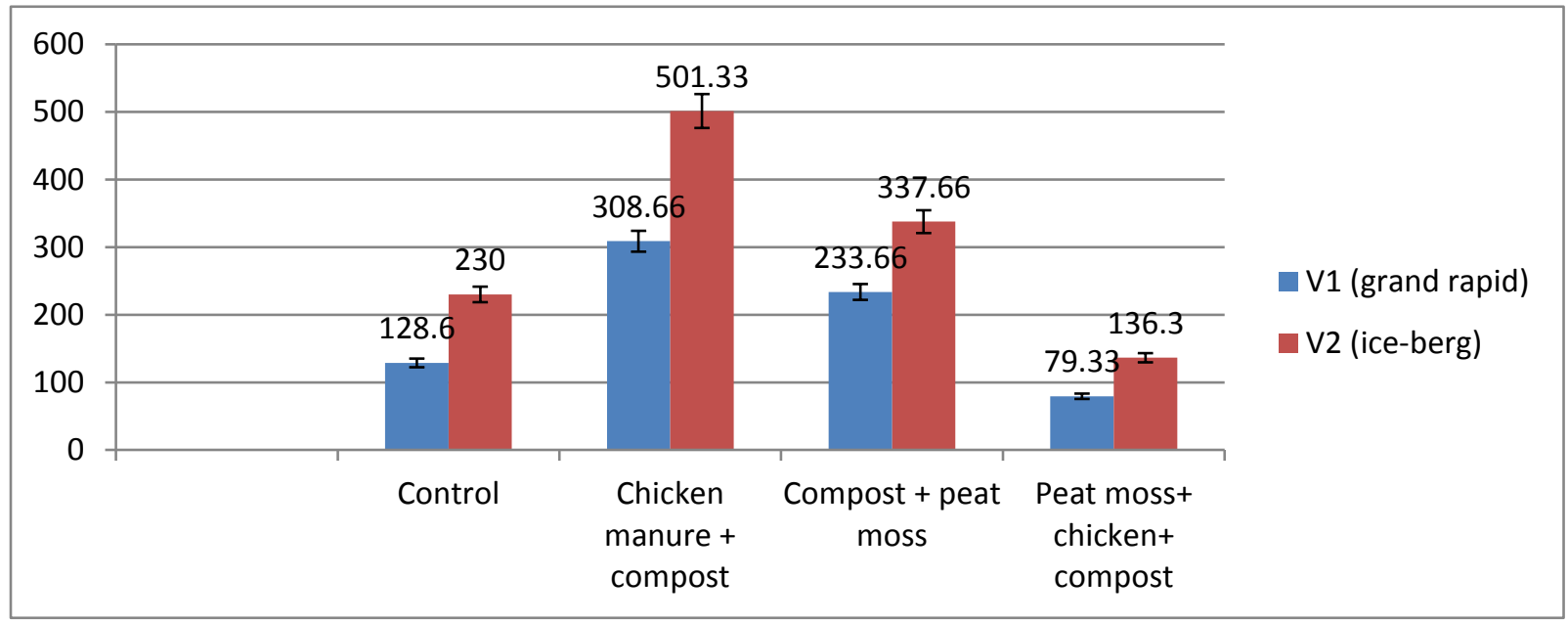

Figure 3. Comparison between mean values of plant fresh weight of two Lettuce Varieties grand rapid and ice-berg using four different manure treatments 


\section{Leaf dry weight}

Leaf dry weight of ice-berg lettuce $(16.4 \mathrm{~g})$ showed significant difference with grand rapid lettuce with $9.8 \mathrm{~g}$. In grand rapid lettuce highest dry matter is recorded in $\mathrm{T}_{1}$ treatment (Chicken manure + compost) with dry weight of $14 \mathrm{~g}$ followed by $\mathrm{T}_{3}$ (Peat moss + chicken + compost) having $11.6 \mathrm{~g}$ dry weight as shown in (Table 5\&Fig. 4) respectively. Least dry weight was observed in plants grown in $\mathrm{T}_{0}$ (Control) alone having $6.6 \mathrm{~g}$ dry weight. For ice-berg, highest dry matter content has been found in heads grown in $\mathrm{T}_{1}$ treatment (Chicken manure + compost) with $23 \mathrm{~g}$ and the lowest dry weight was recorded for $\mathrm{T}_{0}$ (Control) that was $11 \mathrm{~g}$. Mean difference between other treatments are significantly different from highest and lowest values. The current research also supports the report of Masarirambi et al. [15]. According to his study There was a significant $(\mathrm{P}<0.05)$ difference on dry matter among treatments. Dry matter content was higher in plants from the organic fertilizers as compared to other organic fertilizers (As shown in Fig 4). Application of chicken manure to soil enhances concentration of water soluble salts in soil moreover it has high concentration of macro nutrients. It also adds organic matters to the soil to improve soil structure, aeration, soil moisture-holding capacity, and water infiltration 16$]$.

Table 5. leaf dry weight in lettuce varieties grown with different manure treatments

\begin{tabular}{|c|c|c|c|}
\hline Treatments & grand rapid & ice-berg & Mean \\
\hline Control & $6.6 \mathrm{~b}$ & $\mathbf{1 1 a b}$ & $\mathbf{8 . 8 a}$ \\
\hline Chicken manure + compost & $14 \mathrm{~b}$ & $23 \mathrm{a}$ & $\mathbf{1 8 . 5 a}$ \\
\hline Compost + peat moss & $7 \mathrm{~b}$ & $12.3 \mathrm{ab}$ & $\mathbf{9 . 6 b}$ \\
\hline Peat moss+ chicken manure + compost & $11.6 \mathrm{ab}$ & $19.3 \mathrm{a}$ & $\mathbf{1 5 . 4 a}$ \\
\hline Mean & $\mathbf{9 . 8 b}$ & $\mathbf{1 6 . 4 a}$ & \\
\hline
\end{tabular}

Means in the same column or row followed by a common letter (s) are not significantly different at 5\% level by LSD

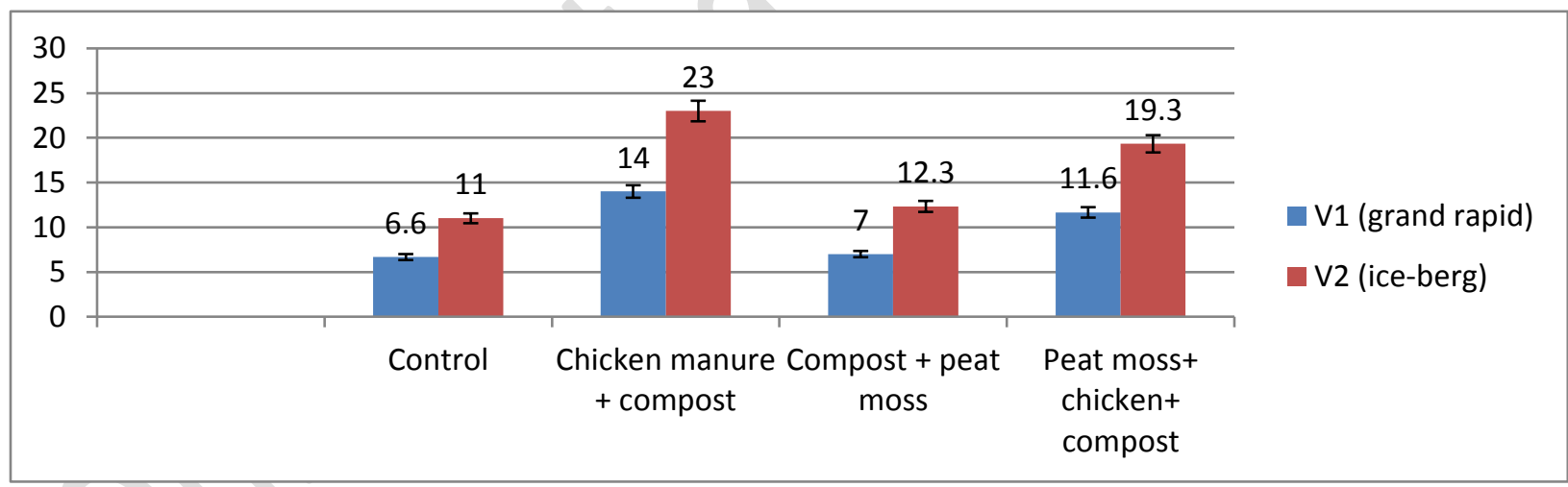

Figure 4.Mean values of leaf dry weight of two Lettuce Varieties using different manure treatments

\section{Organoleptic properties}

Sensory evaluation is an essential criterion for quality judgment in product development and to congregate the consumer requirements. Any product must give pleasure and satisfaction to the consumers if it has to be a part of their eating behavior.
Lettuce is an important vegetable and has potential to increase dietary fiber in our diet. Results pertaining to organoleptic properties of lettuce varieties, Grand rapid (V1) and Iceberg (V2) are presented in (Table 6 \& Fig. 5) respectively. The highest significant values for aroma were 4.5 in ice berg and 3.5 in 
grand rapid grown in Chicken manure + compost $\left(\mathrm{T}_{1}\right)$ and Compost + peat moss $\left(\mathrm{T}_{2}\right)$, respectively. But least values were 2.6 in ice berg and 2.1 in grand rapid $\mathrm{T} 2$ and $\mathrm{T} 3$, respectively. The mean values for flavor of different lettuce varieties have been displayed in (Table 6). The highest significant values for flavor is 4.7 found in plants grown in $\mathrm{T}_{3}$ for the variety $\mathrm{V} 1$ grand rapid lettuce and 4.6 in the plants grown in the $T_{1}$ for variety $V 2$ ice-berg lettuce. It is obvious from result that flavor of both lettuce varieties were significantly different among treatments. The flavor of lettuce variety V2 grown in $\mathrm{T}_{0}$ was kept within acceptable limits; these were ranked as third highest flavor score values. Others with lower values are may be due to inexperienced panelists for flavor. In case of V1, highest rank for flavor was given in all the treatments.

The current research is highly supporting the report of Masarirambi et al. [15]. According to his study Organoleptic tests showed that there were no significant ( $>$ > 0.05) differences in appearance and taste among treatments. Results of this experiment showed that inorganic fertilizers were less suitable in lettuce production in river sand when compared to organic fertilizers. It is recommended that lettuce can be grown successfully using organic fertilizers. In (Fig. 5) shows comparison between mean values of Aroma and flavor of lettuce leaves as affected by media substrates.

Table 6. Organoleptic properties of two lettuce varieties grown with different manure treatments

\begin{tabular}{|c|c|c|c|c|}
\hline Treatments & & grand rapid & ice-berg & Mean \\
\hline \multirow{2}{*}{ Control } & Aroma & $3.2 \mathrm{c}$ & $\mathbf{3 . 4 b c}$ & $\mathbf{3 . 3 b c}$ \\
\cline { 2 - 5 } & Flavor & $3.5 \mathrm{abc}$ & $\mathbf{2 . 7 d}$ & $\mathbf{3 . 1 c}$ \\
\hline \multirow{2}{*}{ Chicken manure + compost } & Aroma & $2.7 \mathrm{~d}$ & $4.5 \mathrm{a}$ & $\mathbf{3 . 6 a b c}$ \\
\cline { 2 - 5 } & Flavor & $3.8 \mathrm{abc}$ & $4.6 \mathrm{a}$ & $\mathbf{4 . 2 a}$ \\
\hline \multirow{2}{*}{ Compost + peat moss } & Aroma & $3.5 \mathrm{bc}$ & $2.6 \mathrm{~d}$ & $\mathbf{3 . 1 c}$ \\
\cline { 2 - 5 } & Flavor & $3.7 \mathrm{abc}$ & $4.3 \mathrm{a}$ & $\mathbf{4 . 0 a b}$ \\
\hline \multirow{2}{*}{ Peat moss+ chicken manure + compost } & Aroma & $2.1 \mathrm{~d}$ & $3.9 \mathrm{ab}$ & $\mathbf{3 . 0 c}$ \\
\cline { 2 - 5 } & Flavor & $4.7 \mathrm{a}$ & $4.1 \mathrm{a}$ & $\mathbf{4 . 4 a}$ \\
\hline
\end{tabular}

Means in the same column or row followed by a common letter (s) are not significantly different at 5\% level by LSD

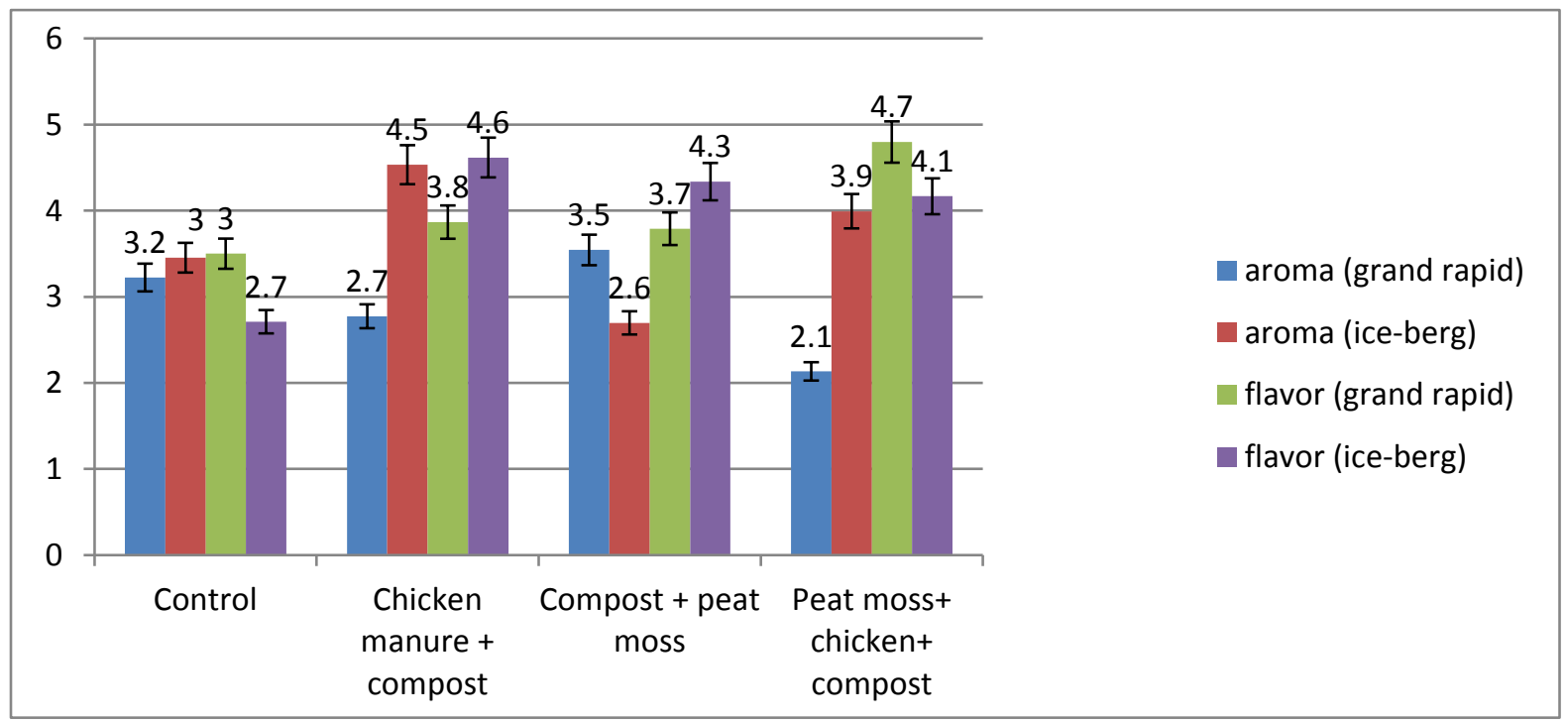

Figure 5. Comparison between mean values of organoleptic properties of two Lettuce Varieties grand rapid and ice-berg using four different manure treatments 


\section{Conclusion}

All the physical attributes were significant among treatments as well as between varieties of lettuce. From this study it was concluded that hybrid varity ice-berg was much better than grand rapid lettuce morphologically. In case of treatments, $\mathrm{T}_{1}$ treatment (chicken manure) was better than other treatments with regards to physical attributes.

\section{Author's Contribution}

Conceived and designed the experiments: N Sajjad\& NY Zahid, Performed the experiments: N Sajjad \& NY Zahid, Analyzed the data: N Khan, Contributed reagents/ materials/ analysis tools: FM Bangulzai, M Ashraf \& RA Baloch, Wrote the paper: FM Bangulzai \& N Sajjad.

\section{References}

1. Service ER (2011). US Dept. of Agriculture. Loss- Adjus food avail data, Vege.

2. Ghanbarian B \& Daigle H (2008). Permeability in two-component porous media. Effective medium approximation compared with lattice-Boltzmann simulations. Vado Zone J 15(2): 10-21.

3. Service NAS (2011). US Dept. of Agriculture. Vege Smry.

4. Baur SR, Klaiber G, Koblo A \& Carle R (2004). Effect of different washing procedures on phenolic metabolism of shredded, packaged iceberg lettuce during storage. J of Agri Food Chem 52: 70177025 .

5. Dupont S, Mondi Z, Willamson G \&. Price $\mathrm{K}$ (2000). Effect of variety, processing, and storage on the flavonoid glycoside and composition of lettuce and chicory. J Agric Food Chem 48: 3957-3964.

6. Nicolle C, Cardinault N, Gueux E, Jaffrelo L, Rock E, Mazur A, Amouroux P \& Rémésy C (2004). Health effect of vegetable-based diet: lettuce consumption improves cholesterol metabolism and antioxidant status in the rat. Clini Nutri 23: 605-614.

7. Rice-Evans CA, Miller NJ \& Paganga G (1997). Antioxidant properties of phenolic compounds. Plan Sci 2: 152-159.
8. Kuntashula, E, Sileshi G, Mafongoya PL \& Banda J (2006). Farmer participatory evaluation of the potential for organic vegetable production in the wetlands of Zambia. Outlook Agr 35: 299-305.

9. Mollitor H, Faber A, Marutzky R \& Springer $\mathrm{S}$ (2004). Peat substitute on the basis of recycled wood chipboard. Acta Horti 644: 123-130.

10. Glime JM (2007). Economic and ethnic uses of Bryophytes. Zander REA (ed.). Flora of Nort Amer Oxfo Uni Press, NY, USA. 14-41.

11. Van AW \&Yoganathan S (2003). Using Kraal Manure as a Fertilizer. ARDRI Fort Hare and the NatiDeptt of AgriReso Cent Dire Comm Govt Prin Pret SA, pp 19.

12. Said JW, Chien K, Takeuchi S, Tasaka T, Asou H, Cho SK, de Vos S, Cesarman E, Knowles DM \& Koeffler HP (1996). Kaposi's sarcoma associated herpesvirus (KSHV or HHV8) in primary effusion lymphoma: ultrastructural demonstration of herpesvirus in lymphoma cells. Blood 87: 4937-4943.

13. Muller JW (1991). Generalized dead times. NuclInstru. Meth Phys Res 301: 543-551.

14. AOAC (1984). Official Methods of Analysis. Association of Official Analytical Chemists. EUA. 14a Ed.Wash DC.

15. Masarirambi MT, Hlawe MM, Oseni OT \& Sibiya TE (2010). Effects of organic fertilizers on growth, yield, quality and sensory evaluation of red lettuce (Lactuca sativa L.) 'VenezaRoxa. Agric Biol J N Am 1(6): 1319-1324.

16. Warman PR (1986). The effect of fertilizer, chicken manure and dairy manure on Timothy yield, tissue composition and soil fertility. Agric 289-298.

17. Oagile D \& Mufwanzala N (2010). Chicken manure-enhanced soil fertility and productivity: Effects of application rates. $J$ Soil Sci \& Env Manag 1(3): 46-54.

18. Dayananda MAI \& Wahundeniya WMKB (2003). Effect of different hydroponic systems and media on growth of lettuce (Lectuca sativa) under protected culture. Hort Sci 33: 237-243. 